F. Reprod. Fert. (1972) 30, 143-146

\title{
PHAGOCYTIC CELLS IN SMEARS FROM INTRAUTERINE DEVICES IN THE BABOON
}

\author{
W. G. BREED, ANNE FRASER, P. EGKSTEIN AND P. V. PEPLOW \\ Department of Anatomy, Medical School, \\ University of Birmingham, Birmingham B15 2 TJ
}

(Received 3rd December 1971, accepted 4th February 1972)

In a recent paper, Sagiroglu \& Sagiroglu (1970) reported findings which have a bearing on the mechanism of action of intrauterine devices (IUDs) in women. By preparing smears directly from Lippes loops ('coil smears') immediately after their removal from the uterus, they claim to have found 'up to 50,000 macrophages on each slide', equivalent to 'more than one million' per device in situ. They think that these cells have so far been overlooked by other workers and believe that they are capable of phagocytosing spermatozoa entering the uterus and, in the event of fertilization, the blastocyst.

Although the authors (Sagiroglu \& Sagiroglu, 1970; Sagiroglu, 1971) show photomicrographs of the macrophages, they have so far given no detailed description of them. Similar cells, interpreted as macrophages, were also found by Joshi (1971) in coil smears taken from baboons. They were, however, present in much smaller numbers (estimated at ' 500 or so' per slide) than those reported by Sagiroglu. Joshi observed no active phagocytosis, but appears to have carried out no special tests to ascertain its occurrence. Very few macrophages were seen in control preparations obtained from the endometrium of baboons without IUDs.

We have, therefore, attempted to obtain direct proof of phagocytic activity in coil smears from baboons fitted with plastic IUDs and to assess the relative numbers of phagocytic cells in such preparations.

The animals used were mature, probably parous and regularly cyclic Papio cynocephalus; full details about them and their management have been given elsewhere (Breed, Stevenson, Eckstein, Peplow \& Butt, 1972). They had been fitted with small, tail-less Margulies coils inserted through the cervix (eight females) or directly through a previously established uterine-cutaneous fistula (two females; see Table 1). The occurrence of ovulation during the experimental cycles was assumed from the persistence of regular swelling and shrinking of the sexual skin, indicating normal progesterone secretion during the luteal phase (cf. Breed et al., 1972). In Table 1, the day on which the device was removed has been related to the beginning of detumescence of the sexual skin (= Day 0 in the Table), which itself is known to occur 2 to 3 days after ovulation (Hendrickx \& Kraemer, 1969).

In order to demonstrate the possible phagocytic properties of the cellular elements in the smears, about $3 \mathrm{ml}$ of a solution of sterile Indian ink (G. T. Gurr, London), a vital dye (cf. Culling, 1963), was injected into the uterine 
cavity by means of a special flushing device (Peplow, Breed, Smith \& Eckstein, in preparation). Five to $24 \mathrm{hr}$ later, the IUD was removed from five females per vaginam with a Paterson biopsy forceps, from three females by hysterotomy or directly from two females with uterine-cutaneous fistulae (Table 1). Coil smears were then prepared from the IUDs exactly as described by Sagiroglu \& Sagiroglu (1970). The slides were fixed in $70 \%$ ethanol:ether $(1: 1)$ and stained by Papanicolaou's method, after which differential counts were carried out. To allow for possible uneven distribution of cells, three slides were usually examined for each coil removed; the results are listed in Table 1.

In an attempt to see whether the presence of Indian ink as such can affect the cellular composition of coil smears, Indian ink was injected and an IUD inserted into the uterus in five (control) baboons. Five to $6 \mathrm{hr}$ later, the IUD was removed and smears were prepared from it as in the case of the experimental animals.

Cells present were identified by their general cytological characteristics, while phagocytic activity was inferred from the ability of the cells to ingest particles of the injected Indian ink. Plate 1 clearly demonstrates such activity both among macrophages and polymorphonuclear leucocytes. The latter outnumbered the macrophages in smears from eight out of ten coils (see Table 1, last column). Neither the absolute number of macrophages nor the proportion of phagocytic ones among them in a given smear could be determined with certainty. Their morphological features were not always sufficiently distinct to permit complete identification, while not all the cells resembling macrophages in shape and size took up Indian ink. Such cells may have been macrophages not actively phagocytic at the time of sampling or cells derived from the utero-cervical epithelium or stroma. The ratio of phagocytic macrophages to total nucleated cells was $7 \cdot 6 \pm 1 \cdot 2 \%$ (mean \pm S.E.). It is also clear from Table 1 that a considerable proportion $(64.6 \% \pm 6.0$, S.E.) of the nucleated cells present in coil smears were polymorphonuclear leucocytes, of which a variable number $(27 \cdot 2 \pm 6 \cdot 4 \%$, S.E.) took up Indian ink. In the experimental animals, neither the stage of the menstrual cycle nor the method of removing the IUD or the length of time between its insertion and removal appeared to influence the relative frequency of the various cells observed (see Table 1). The smears prepared from control animals also contained cells, but macrophages were very scarce and present in significantly smaller numbers than in the experimental group $(1.4 \%$ versus $7.6 \% ; P<0.01)$.

These results confirm Joshi's report (1971) that macrophages occur in coil smears obtained from baboons and further show that some of these cells take

\section{EXPLANATION OF PLATE 1}

Figs 1 to 4 show coil smears prepared from IUDs in baboons.

FiG. 1. Two large macrophages (arrowed) with ingested particles of Indian ink, and a cluster of epithelial cells, probably of uterine origin $(\mathrm{ep})$, without ink particles. $\times 250$.

Fig. 2. Macrophage (arrowed) with ingested cytoplasmic particles of Indian ink and a cell with a similar vesicular nucleus but without ink particles (arrowed). $\times 550$.

FIG. 3. Polymorphonuclear leucocyte with ingested particles of Indian ink, adjacent to two polymorphs without particles. $\times 1010$.

FIG. 4. Multinucleate giant cell macrophage with numerous cytoplasmic particles of Indian ink. $\times 550$. 
PLATE 1
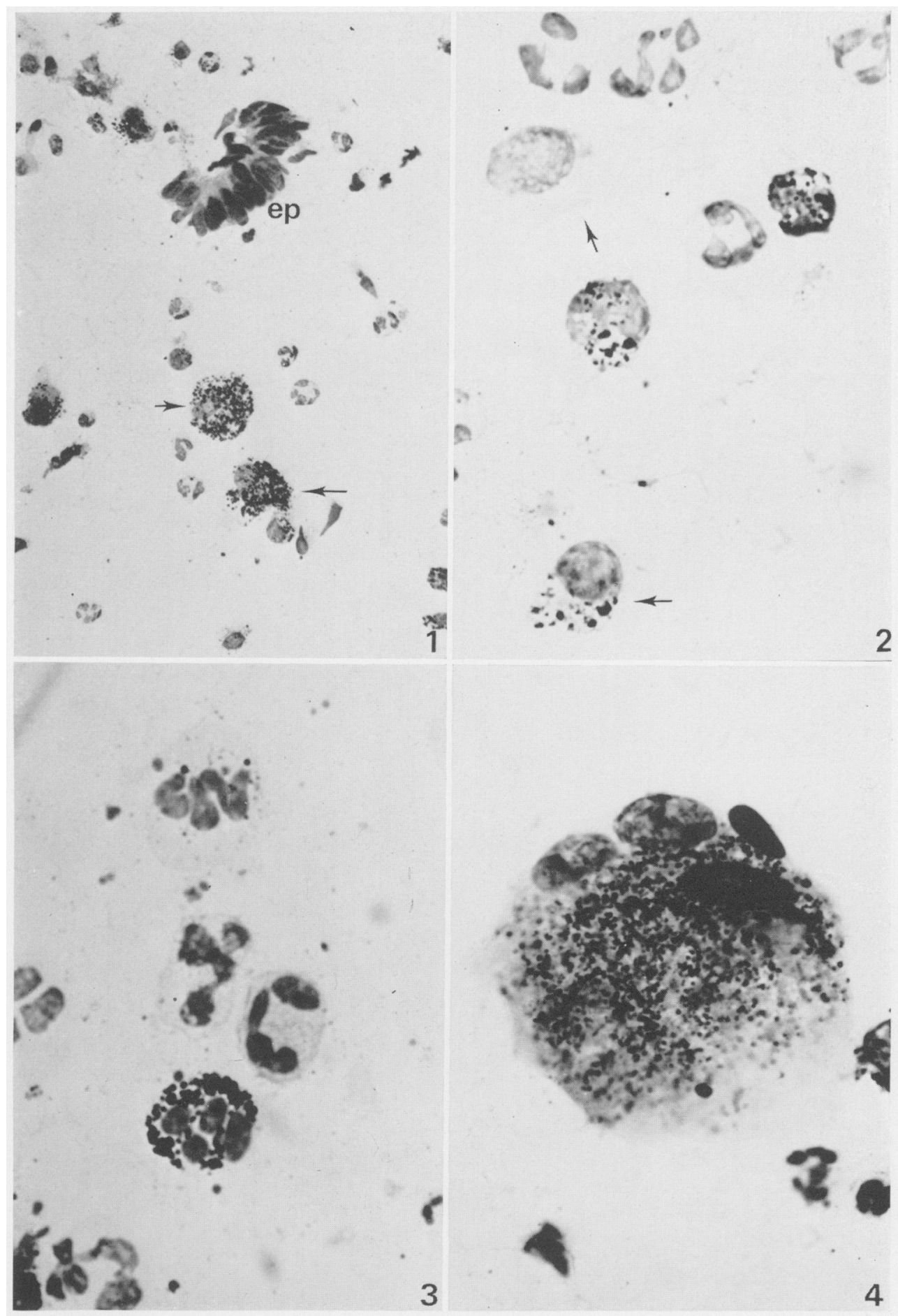

(Facing p. 144) 


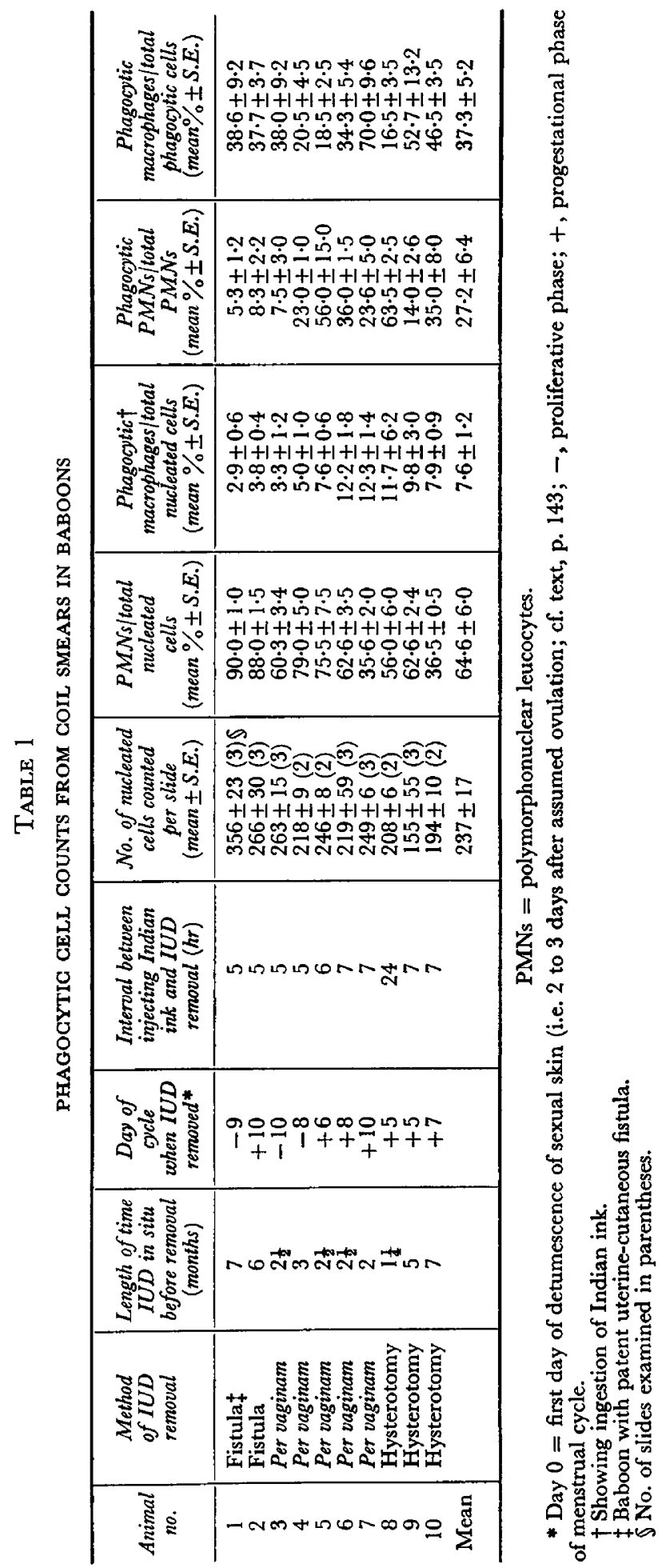


up Indian ink in vivo and so may be considered phagocytic. This does not, of course, prove that they were equally capable of ingesting either live spermatozoa or fertilized ova. We were unable to investigate this point further because of the lack of male baboons in our colony. The few cells found in smears from control baboons could have been equally due to the injected Indian ink or to the presence of the IUD in the uterus for $6 \mathrm{hr}$.

Our findings differ, however, from those of Joshi and of Sagiroglu and Sagiroglu, in that we observed a relatively high proportion of polymorphs, both phagocytic and non-phagocytic, among the nucleated cells in smears from experimental animals. The ability of polymorphs to ingest spermatozoa within the uterus is well established for a number of species, e.g. rat and mouse (Austin, 1957), hamster (Yanagimachi \& Chang, 1963), rabbit (Moyer, Legorreta, Maruta \& Henderson, 1967) and man (Moyer, Rimdusit \& Mishell, 1970).

Up to now, it has been generally assumed that IUDs in primates are mainly ovotoxic or anti-nidatory and probably interfere only marginally, if at all, with fertilization (cf. Marston, Kelly \& Eckstein, 1969; EI Sahwi \& Moyer, 1970; Eckstein, 1972). It may be, however, that they also cause an accumulation of phagocytic cells in the uterine lumen, as a result of which the number of viable spermatozoa reaching the Fallopian tube is critically reduced. If such phagocytic cells are important it appears that, in baboons, both macrophages and polymorphs are involved.

The financial support of the Ford Foundation in the conduct of this work is gratefully acknowledged.

\section{REFERENGES}

Austin, G. R. (1957) Fate of spermatozoa in the uterus of the mouse and rat. F. Endocr. 14, 335.

Breed, W. G., Stevenson, J., Eckstein, P., Peplow, P. V. \& Butt, W. R. (1972) Effect of an intrauterine device on menstrual cyclicity and luteal function in the baboon. F. Reprod. Fert. 28, 249.

Culling, C. F. A. (1963) Handbook of histopathological techniques, 2nd edn, p. 404. Butterworths, London.

Ecxstein, P. (1972) Recent research on the mode of action of intra-uterine devices in primates. Acta endocr., Copenh. Suppl. (in press).

EL SAHWi, S. \& MoYer, D. L. (1970) Antifertility effect of the intrauterine foreign body. Contraception, 2,1 .

Hendrickx, A. G. \& Kraemer, D. G. (1969) Observations on the menstrual cycle, optimal mating time and preimplantation embryos of the baboon, Papio anubis and Papio cynocephalus. 7. Reprod. Fert., Suppl. 6, 119.

Joshi, S. G. (1971) Accumulation of macrophages in the uterine cavity of baboons bearing an intrauterine foreign body (IUFB). Contraception, 4, 45 .

Marston, J. H., Kelly, W. A. \& Eckstein, P. (1969) Effect of an intrauterine device on gamete transport and fertilization in the rhesus monkey. F. Reprod. Fert. 19, 149.

Moyer, D. L., Legorreta, G., Maruta, H. \& Henderson, V. (1967) Elimination of homologous spermatozoa in the female genital tract of the rabbit: a light and electron-microscope study. 7. Path. Bact. 94, 345.

Moyer, D. L., Rimdustr, S. \& Mishell, D. R., JR (1970) Sperm distribution and degradation in the human female reproductive tract. Obstet. Gynec., N.Y. 35, 831.

Sagiroglu, N. (1971) Phagocytosis of spermatozoa in the uterine cavity of woman, using intrauterine device. Int. F. Fert. 16, 1.

Sagiroglu, N. \& Sagiroglu, E. (1970) Biologic mode of action of the Lippes loop in intrauterine contraception. Am. 7. Obstet. Gynec. 106, 506.

YanaGimachi, R. \& Ghang, M.G. (1963) Infiltration of leucocytes into the uterine lumen of the golden hamster during the oestrous cycle and following mating. F. Reprod. Fert. 5, 389. 